\title{
Analisis Kinerja Keuangan Pada Perusahaan Manufaktur Sektor Farmasi di Bursa Efek Indonesia
}

\author{
SETIAWATI \\ Dosen Tetap Sekolah Tinggi Ilmu Ekonomi Persada Bunda \\ Jln. Diponegoro No. 42 (0761)23181 Pekanbaru \\ E-mail : setiawatieci@gmail.com
}

\begin{abstract}
This study aims to analyze and assess the financial performance of the pharmaceutical sector manufacturing companies on the Indonesia Stock Exchange in the 2015-2017 period based on liquidity ratios, activity ratios, profitability ratios, and solvency ratios. This type of research uses quantitative research. This study uses secondary data in the form of company financial statements and the determination of samples using purposive sampling technique. The analysis method used in this research is financial ratio analysis. The results of the study based on the overall financial ratios both based on liquidity ratios, activity ratios, profitability ratios and solvency ratios indicate that the Sido Muncul Herbal Medicine and Pharmacy Industry has the best financial performance compared to other pharmaceutical sector manufacturing companies.
\end{abstract}

Keywords: Financial Performance Analysis, Ratio Analysis

Industri manufaktur merupakan salah satu sektor industri yang mendominasi perusahaan-perusahaan yang terdaftar di Bursa Efek Indonesia (BEI). Tahun 2016 sektor ini salah satu penyumbang investasi terbesar di Indonesia. Salah satu sub sektor industri manufaktur yang diprediksi akan terus berkembang sehingga diprediksi mampu mencapai pertumbuhan di tahun 2017 paling tidak 10\% yang sebelumnya hanya mencapai $7 \%$ adalah perusahaan farmasi. Hal ini sejalan dengan semakin besarnya peranan perusahaan dalam pelayanan kesehatan (Warta Kota, 2017). Agar tetap bertahan maka perusahaan dalam industri tersebut harus semakin meningkatkan kinerjanya guna mencapai tujuan semaksimal mungkin dan mampu bersaing secara global.

Dalam meningkatkan kinerja
perusahaan tentu tergantung pada kemampuan manajemen keuangan dalam menganalisis kinerja keuangan perusahaan yang diperoleh dari laporan keuangan dimana laporan keuangan ini berfungsi sebagai sumber informasi utama.

Dalam menganalisis kinerja keuangan perusahaan, hal yang harus diperhatikan adalah bagaimana likuiditas perusahaan, apakah manajemen mengumpulkan laba operasi yang cukup atas aktiva perusahaan, bagaimanakah perusahaan membelanjakan aktivanya dan apakah para pemilik menerima pengembalian yang pantas atas investasi mereka. Untuk menjawab pertanyaan ini, maka perusahaan menggunakan analisis rasio keuangan (Keown dkk, 2011).

Analisis rasio keuangan adalah suatu angka yang menunjukkan hubungan antara unsur-unsur dalam laporan keuangan (Sugiono, 2009:64 dalam Khatami dkk (2017)). Rasio keuangan membantu kita untuk mengidentifikasi beberapa kelemahan dan kekuatan keuangan perusahaaan (Keown, dkk (2011:74)).

Analisis rasio digunakan oleh tiga kelompok utama yaitu (1) manajer, yang menggunakan rasio untuk menganalisis, mengendalikan, dan memperbaiki operasi perusahaan, (2) analis kredit termasuk petugas pinjaman bank dan analis pemeringkat obligasi,(3) analis saham, yang tertarik dengan prospek efesiensi, resiko, dan pertumbuhan perusahaan (Houston, 2012). 
Secara garis besar ada empat jenis rasio (Herdiananda, 2017), antara lain: Rasio likuiditas, Rasio yang menunjukkan hubungan antara kas perusahaan dan aktiva lancar lainnya dengan hutang lancar. Rasio ini digunakan untuk mengukur kemampuan perusahaan dalam memenuhi kewajibankewajiban finansialnya yang harus segera dipenuhi atau kewajiban jangka pendek. 1) Current Ratio (Rasio Lancar), Rasio lancar adalah rasio yang digunakan untuk mengukur kemampuan likuiditas jangka pendek perusahaan dengan melihat aktiva lancar perusahaan relatif terhadap hutang lancarnya (kewajiban perusahaan). 2) Quick Ratio (Rasio Cepat), Rasio cepat adalah kemampuan untuk membayar hutang yang harus segera dipenuhi oleh aktiva lancar yang lebih likuid (quick asset).

Rasio aktivitas, Rasio keuangan yang mengukur bagaimana perusahaan secara efektif mengelola aktiva-aktivanya. Rasio ini digunakan untuk melihat seberapa besar tingkat aktiva tertentu yang dimiliki perusahaan, apakah sudah sesuai dan beralasan, sangat tinggi atau sangat rendah jika dipandang dari tingkat penjualan saat ini. Semakin tinggi rasio aktivitas semakin efektif perusahaan dalam mendayagunakan sumber dayanya. 1) Total Assets Turn Over, Total assets turn over dalah rasio antara penjualan dengan total aktiva yang menyetujui efisiensi penggunaan aktiva secara keseluruhan. 2) Inventory Turn Over ,Inventory turn over Digunakan untuk mengukur efisiensi pengelolaan persediaan barang dagang. Rasio ini merupakan informasi yang cukup popular untuk menilai efeisiensi operasional yang memperlihatkan seberapa baiknya manajemen mengontrol modal yang ada pada persediaan.

Rasio profitabilitas, Rasio yang menunjukkan kemampuan perusahaan untuk memperoleh keuntungan dari penggunaan modalnya. 1) Net Profit Margin, Net profit margin adalah rasio yang mengukur seberapa banyak keuntungan operasional yang bisa diperoleh Jurnal Daya Saing (Vol. 4, No. 3 Oktober 2018) dari setiao rupiah penjualan. 2) Return On Assets, Return on assets adalah rasio antara laba setelah pajak dengan total aktiva. Rasio ini mengukur tingkat keuntungan yang dihasilkan dari investasi total, 3) Return On Equity, Return on equity (ROE) adalah jumlah imbal hasil dari laba bersih terhadap ekuitas dan dinyatakan dalam bentuk persen.

Rasio solvabilitas, Rasio solvabilitas adalah rasio yang menunjukan kemampuan perusahaan untuk memenuhi kewajiban keuangan jangka panjangnya. 1) Debt To Assets Rasio, Debt to assets ratio merupakan rasio utang yang digunakan untuk mengukur perbandingan antara total hutang dengan total aktiva. 2) Debt to Equity Rasio, Debt to equity ratio menggambarkan perbandingan antara kewajiban dan ekuitas dalam pendanaan perusahaan dan menunjukan modal perusahaan itu sendiri dalam memenuhi seluruh kewajiban perusahaan.

Penelitian-penelitian untuk mengetahui kinerja perusahaan yang didasarkan pada rasio keuangan pernah dilakukan sebelumnya oleh Agustin et al (2013) menunjukan bahwa PT. Indocement Tunggal Prakasa tbk dapat dikatakan likuid dibandingkan dengan PT. Holcim indonesia tbk dan PT. Semen Gresik tbk karena rasio likuiditasnya lebih dari 200\% sehingga perusahaan mampu memenuhi kewajiban-kewajiban jangka pendeknya. Janaloka (2015) Hasil penelitiannya tersebut menunjukan bahwa ketiga perusahaan yang diteliti yaitu PT.Telkomsel Tbk, PT.indosat Tbk, dan PT.smartfren Tbk masih belum bisa dikatakan likuid karena rasio likuiditasnya kurang dari 200\% sehingga perusahaan perlu menghindari keputusan yang bersifat mengejar keuntungan yang bersifat jangka pendek, namun mampu memberikan kerugian bersifat jangka panjang. Recly Bima Rhamadana (2016) “ Analisis Rasio Keuangan Untuk Menilai Kinerja Keuangan Pada PT. H.M Sampoerna Tbk" Hasil penelitian ini berdasarkan rasio likuiditas yang

p.ISSN: $2407-800 X \quad$ e.ISSN: 2541-4356 
diproksikan Current Ratio dan Quick Ratio kondisi kinerja keuangan perusahaan kurang baik. Rasio profitabilitas yang diproksikan Net Profit Margin, Return on Assets, dan Return on Equity kondisi kinerja keuangan perusahaan baik. Rasio solvabilitas yang diproksikan Debt to Total Assets Ratio dan Debt to Total Equity Ratio kondisi kinerja keuangan perusahaan baik. Rasio aktivitas yang diproksikan Total Assets Turn Over dan Fixed Assets Turn Over kondisi kinerja keuangan perusahaan baik.

\section{METODE}

Penelitian ini dilakukan dengan menggunakan laporan keuangan perusahaan manufaktur sektor industri farmasi di Bursa Efek Indonesia. Penentuan sampel dalam penelitian ini berdasarkan pada metode purposive sampling, dimana sampel perusahaan dipilih berdasarkan pada kriteria tertentu. Dalam penelitian ini sampel yang diambil memiliki kriteria-kriteria sebagai berikut:

1. Perusahaan manufaktur sektor farmasi yang terdaftar di Bursa efek Indonesia 2015 sampai tahun 2017.

2. Perusahaan manufaktur sektor farmasi yang menerbitkan laporan keuangan lengkap dari tahun 20152017.

3. Perusahaan manufaktur sektor farmasi yang didalam laporan keuangannya dinyatakan dalam Rupiah.

Data yang digunakan dalam penelitian ini adalah data sekunder. Teknik pengumpulan datanya tersebut diperoleh dari website BEI yaitu www.idx.co.id yang berupa laporan laba rugi, neraca tahunan perusahaan manufaktur sektor farmasi mulai tahun 2015 sampai tahun 2017 dan studi kepustakaan, yaitu dengan mencari informasi-informasi tertulis yang berkaitan dengan penelitian ini.

Metode analisis yang digunakan adalah metode analisis horizontal yaitu analisa yang mengadakan perbandingan laporan keuangan untuk beberapa saat sehingga akan diketahui perkembangannya. Adapun teknik analisa yang dipakai dalam penelitian ini adalah sebagai berikut :

1. Menghitung rasio keuangan perusahaan manufaktur sektor farmasi dengan menggunakan rasio likuiditas, rasio aktivitas, rasio profitabilitas dan rasio solvabilitas selama tahun 2015-2017.

2. Membandingkan rasio keuangan perusahaan manufaktur sektor farmasi di Bursa Efek Indonesia periode 2015-2017.

3. Melakukan penilaian terhadap kinerja keuangan perusahaan manufaktur sektor farmasi di Bursa Efek Indonesia periode 2015-2017 berdasarkan rasio keuangan.

4. Mengambil kesimpulan tentang kinerja keuangan perusahaan sektor farmasi di Bursa Efek Indonesia periode 2015-2017 berdasarkan rasio keuangan.

\section{HASIL}

Berdasarkan hasil, dapat diketahui bahwa Current Ratio dan Quick Ratio Perusahaan Sektor Farmasi di Bursa Efek Indonesia periode 2015-2017 cenderung mengalami fluktuasi.

Menurut Kasmir (2008:143), standar industri untuk current ratio adalah $200 \%$, dimana perusahaan yang mampu memenuhi standar industri selama periode 2015 sampai 2017 adalah Darya Varia Labor Tbk dengan rata-rata sebesar 301\%, Kalbe Farma Tbk dengan rata-rata sebesar $411 \%$, Merck Tbk dengan rata-rata sebesar $365 \%$, Pyridam Farma Tbk dengan rata-rata sebesar 262\%, PT Industri Jamu dan Farmasi Sido Muncul Tbk dengan rata-rata sebesar $847 \%$ dan Tempo Scan Pacific Tbk dengan rata-rata sebesar $257 \%$. Berdasarkan hasil perhitungan menunjukan bahwa rasio likuiditas dengan current ratio paling baik adalah PT. Industri Jamu dan Farmasi Sido Muncul Tbk terlihat dengan rata-rata rasio yang dimiliki sebesar $847 \%$ lebih besar bila dibandingkan dengan ketiga perusahaan farmasi yang lain. 
Standar industri untuk quick ratio adalah 150 $\%$ (Kasmir, 2008:143) dimana perusahaan yang memenuhi standar industri adalah Darya Varia Labor Tbk sebesar 245\%, Kalbe Farma Tbk sebesar 268\%, Merck Tbk sebesar 209\%, PT. Industri Jamu dan Farmasi Sido Muncul Tbk sebesar 707\% dan Tempo Scan Pacific Tbk sebesar 181\%. Dari hasil perhitungan menunjukkan rasio likuiditas dengan quick ratio yang paling baik adalah PT Industri Jamu dan Farmasi Sido Muncul Tbk, ini berarti PT Industri Jamu dan Farmasi Sido Muncul Tbk memiliki aktiva lancar diluar persediaan lebih besar yaitu $707 \%$ bila dibandingkan dengan perusahaan farmasi yang lain.

Berdasarkan hasil, dapat diketahui bahwa Total Asset Turn Over Perusahaan Sektor Farmasi di Bursa Efek Indonesia periode 2015-2017 cenderung mengalami fluktuasi. Sedangkan, Inventory Turn Over Perusahaan Sektor Farmasi di Bursa Efek Indonesia periode 2015-2017 cenderung mengalami fluktuasi juga.

Menurut Kasmir (2008:187) standar untuk total assets turn over atau perputaran total aktiva adalah sebanyak 2 kali, maka kedelapan perusahaan sampel penelitian dapat dikatakan memiliki kinerja yang baik karena berada diatas standar industri. Berdasarkan hasil perhitungan menunjukan perputaran total aktiva yang paling baik adalah PT Industri Jamu dan Farmasi Sido Muncul Tbk, ini terlihat dari perputaran semua harta untuk menghasilkan penjualan bersih dimana PT Industri Jamu dan Farmasi Sido Muncul Tbk memiliki nilai yang lebih baik yaitu sebanyak 5 kali dibandingkan dengan ketujuh perusahaan farmasi lainnya.

Menurut Kasmir (2008:187) standar untuk inventory turn over atau perputaran persediaan adalah sebanyak 20 kali, maka kedelapan perusahaan sampel penelitian dapat dikatakan memiliki kinerja yang kurang baik karena berada dibawah standar industri, namun jika dilihat dari rata-rata perusahaan sampel penelitian untuk inventory turn over perusahaaan yang memiliki rata-rata tertinggi adalah Kimia Farma (Persero) Tbk dan Merck Tbk
Sebanyak 1.4 artinya mempunyai tingkat inventory turn over yang lebih baik dibandingkan ketujuh perusahaan farmasi lainnya.

Berdasarkan hasil, dapat diketahui bahwa Net Present Value, Return On Asset dan Return On Equity Perusahaan Sektor Farmasi Di Bursa Efek Indonesia periode 2015-2017 cenderung mengalami fluktuasi.

Menurut Kasmir (2008:208) standar industri untuk net profit margin adalah $20 \%$ dimana berdasarkan hasil perhitungan menunjukan net profit margin yang paling baik adalah PT. Industri Jamu dan Farmasi Sido Muncul Tbk, ini terlihat dari laba setiap penjualan yang dihasilkan PT. Industri Jamu dan Farmasi Sido Muncul Tbk yaitu dengan laba sebesar 20\% dibandingkan dengan ketujuh perusahaan farmasi lainnya.

Menurut Kasmir (2008:208) standar industri untuk return on assets adalah sebesar $30 \%$, dimana tidak ada perusahaan yang memenuhi standar industri sedangkan perusahaan yang memiliki nilai rata-rata tertinggi adalah Merck Tbk yaitu sebesar $20 \%$ dibandingkan perusahaan farmasi lainnya.

Menurut Kasmir (2008:208) standar industri untuk return on equity adalah sebesar $40 \%$ dimana tidak ada perusahaan yang memenuhi standar industri ini, Sedangkan perusahaan yang mempunyai nilai rata-rata tertinggi adalah Merck Tbk dengan nilai return on equity sebesar $27 \%$ yang menunjukan bahwa rata-rata rasio nya lebih baik daripada rata-rata rasio perusahaan farmasi lainnya.

Berdasarkan hasil, dapat diketahui bahwa Debt to Asset Ratio dan Debt to Equity Ratio Perusahaan Sektor Farmasi periode 2015-2017 cenderung mengalami fluktuasi.

Menurut Kasmir (2008:208) standar industri untuk debt to assets ratio adalah sebesar $35 \%$ dimana perusahaan yang memenuhi standar industri adalah Darya Varia Labor Tbk sebesar 30\%, Kalbe Farma Tbk sebesar $18 \%$, Merck Tbk sebesar $25 \%$, Pyridam Farma Tbk sebesar 35\%, Industri 
Jamu dan Farmasi Sido Muncul Tbk sebesar 10\%, dan Tempo Scan Pacific Tbk sebesar $31 \%$, karena semakin kecil rasio ini dari ratarata perusahaan sampel penelitian semakin baik.

Sedangkan Indofarma Tbk dan Kimia Farma (Persero) Tbk memiliki aktiva lebih banyak dibiayai oleh hutang dimana rata-rata debt to asset ratio sebesar $62 \%$ dan $50 \%$.

Menurut Kasmir (2008:208) standar industri untuk debt to equity ratio adalah sebesar $90 \%$ dimana perusahaan yang memenuhi standar industri adalah Darya Varia Labor Tbk sebesar 43\%, Kalbe Farma Tbk sebesar 22\%, Merck Tbk sebesar 34\%, Pyridam Farma Tbk sebesar 54\%, Industri Jamu dan Farmasi Sido Muncul Tbk sebesar 10\%, dan Tempo Scan Pacific Tbk sebesar $44 \%$, karena semakin kecil rasio ini dari ratarata perusahaan sampel penelitian semakin baik.

Sedangkan Indofarma Tbk dan Kimia Farma (Persero) Tbk dalam kegiatan produksinya lebih banyak dibiayai oleh hutang daripada modal sendiri dimana ratarata debt to equity ratio sebesar $164 \%$ dan $102 \%$.

\section{PEMBAHASAN}

Berdasarkan hasil analisis dengan menggunakan rasio keuangan yang terdiri dari rasio likuiditas, rasio aktivitas, rasio profitabilitas, dan rasio solvabilitas maka dapat dinilai kinerja perusahaan Perusahaan Sektor Farmasi di Bursa Efek Indonesia periode 2015-2017.

Rasio likuiditas yang diproksi dengan current ratio dan quick ratio paling baik adalah PT. Industri Jamu dan Farmasi Sido Muncul Tbk artinya perusahaan memiliki kinerja yang baik karena rasio yang dimiliki memenuhi standar dan lebih besar bila dibandingkan dengan keempat perusahaan farmasi tersebut.

Rasio aktivitas ini diproksi dengan total asset turn over ratio dan inventory turn over ratio. Berdasarkan hasil maka total asset turn over ratio seluruh sampel dalam penelitian ini dapat dikatakan perusahaan lebih efisien dalam menggunakan aktivanya untuk menghasilkan penjualan artinya perusahaan memiliki kinerja yang baik. Bila dibandingkan dengan perusahaan yang menjadi sampel tersebut maka PT Industri Jamu dan Farmasi Sido Muncul Tbk menunjukkan kinerja yang lebih baik sedangkan inventory turn over ratio seluruh sampel penelitian dapat dikatakan memiliki kinerja yang kurang baik dimana jika dilihat dari rata-rata perusahaan sampel penelitian maka nilai inventory turn over ratio yang tertinggi adalah Kimia Farma (Persero) Tbk dan Merck Tbk.

Berdasarkan hasil maka net profit margin PT. Industri Jamu dan Farmasi Sido Muncul Tbk menunjukkan kinerja yang baik karena laba setiap penjualan yang dihasilkan mampu memenuhi standar industri, sedangkan return on assets ratio dan return on equity ratio, seluruh sampel penelitian memiliki kinerja kurang baik dimana rasio Merck Tbk merupakan nilai yang tertinggi.

Berdasarkan hasil, debt to asset ratio perusahaan Darya Varia Labor Tbk, Kalbe Farma Tbk, Merck Tbk, Pyridam Farma Tbk, Industri Jamu dan Farmasi Sido Muncul Tbk, dan Tempo Scan Pacific Tbk, memiliki kinerja yang baik karena perusahaan kecil menggunakan hutang untuk aktivanya sedangkan Indofarma Tbk dan Kimia Farma (Persero) Tbk sebaliknya dimana memiliki aktiva lebih banyak dibiayai oleh hutang.

Berdasarkan hasil debt to equity ratio yang diperoleh perusahaan Darya Varia Labor Tbk, Kalbe Farma Tbk, Merck Tbk, Pyridam Farma Tbk, Industri Jamu dan Farmasi Sido Muncul Tbk, dan Tempo Scan Pacific Tbk memiliki kinerja baik karena perusahaan kecil dibiayai oleh hutang sedangkan Indofarma Tbk dan Kimia Farma (Persero) Tbk sebaliknya yaitu lebih banyak dibiayai oleh hutang daripada modal sendiri dalam kegiatan produksinya sehingga berdampak semakin besar beban yang akan ditanggungnya.

p.ISSN: $2407-800 X$

e.ISSN: $2541-4356$ 


\section{SIMPULAN}

Atas dasar hasil analisis dan pembahasan, maka dapat ditarik kesimpulan sebagai berikut:

1. Rasio likuiditas yang diproksi dengan current ratio dan quick ratio menunjukkan bahwa Industri Jamu dan Farmasi Sido Muncul Tbk memiliki tingkat likuiditas yang tinggi. Ini mencerminkan kemampuan Industri Jamu dan Farmasi Sido Muncul Tbk dalam membayar hutang lancarnya tinggi.

2. Rasio aktivitas perusahaan manufaktur sektor farmasi yang diproksi dengan total asset turn over ratio berbanding terbalik dengan inventory turn over ratio karena memiliki kinerja kurang baik dimana berada dibawah standar industri artinya perusahaan belum efisien dalam memanfaatkan persediaan yang dimiliki perusahaan.

3. Profitabilitas perusahaan manufaktur sektor farmasi yang diproksi dengan return on assets ratio dan return on equity ratio memiliki kinerja kurang baik karena berada dibawah standar industri. Sedangkan net profit margin ratio yang memenuhi standar adalah hanya perusahaan Industri Jamu dan Farmasi Sido Muncul yang menunjukkan kinerja yang lebih baik dalam menghasilkan laba bersih.

4. Solvabilitas yang diproksi dengan debt to assets ratio dan debt to equity ratio menunjukkan bahwa Indofarma Tbk Kimia Farma Tbk dan Pyridam Farma Tbk memiliki kinerja kurang baik karena berada dibawah standar industri artinya perusahaan tersebut lebih banyak dibiayai oleh hutang yang berdampak semakin besar beban yang akan ditanggungnya bila dibandingkan perusahaan lainnya.

\section{DAFTAR RUJUKAN}

Brigham and Houston., 2012., Dasar-Dasar Manajemen
Keuangan., Edisi 11., Salemba Empat., Jakarta.

Herdiananda., 2017., Analisis Kinerja Keuangan Pada Perusahaan Batubara yang Terdaftar di BEI., Jurnal Ilmu dan Riset Manajemen Administrasi Bisnis., Vol.6., No.1.

Keown dkk., 2011., Manajemen Keuangan., Edisi Kesepuluh., Indeks., Jakarta.

Khatami dkk.., 2017., Analisis Kinerja Keuangan Perusahaan Sebelum dan Sesudah Initial Public Offering (IPO) di Bursa Efek Indonesia (Studi pada Perusahaan Non Finansial yang Listing di BEI Tahun 2011)., Jurnal Administrasi Bisnis., Vol.47., No.1.

Nikmah dkk.., 2017., Analisis Rasio Keuangan Dalam Du Pont System Sebagai Dasar Untuk Mengukur Kinerja Keuangan Perusahaan (Studi pada Nippon Indosari Corpindo, Tbk yang Terdaftar Pada BEI Periode 2010-2012).,

Oktania dkk.., 2013., Analisis Profitabilitas dan Likuiditas Dalam Menilai Kinerja Keuangan Pada PT Telekomunikasi Indonesia, Tbk., Jurnal Ilmu dan Riset Manajemen Administrasi Bisnis., Vol.2., No.3.

www.idx.co.id dalam perusahaan yang tercatat, laporan tahunan mulai tahun 2015 sampai tahun 2017. 